\title{
Assault from all sides: hybridization and introgression threaten the already critically endangered Myuchelys georgesi (Chelonia: Chelidae)
}

\author{
A. Georges ${ }^{1, *}$, R. J. Spencer ${ }^{2}$, A. Kilian ${ }^{3}$, M. Welsh ${ }^{1}$, X. Zhang ${ }^{1}$ \\ ${ }^{1}$ Institute for Applied Ecology, University of Canberra, ACT 2601, Australia \\ ${ }^{2}$ Hawkesbury Institute for the Environment and School of Science and Health, Western Sydney University, Locked Bag 1797, \\ Penrith, NSW 2751, Australia \\ ${ }^{3}$ Diversity Arrays Technology Pty Ltd, University of Canberra, ACT 2601, Australia
}

\begin{abstract}
Hybridization and introgression between species is remarkably common, even between distantly related taxa. This suggests that the frequency of hybridization between species has been greatly constrained, not by evolutionary divergence in isolation, but by lack of opportunity. This constraint is being relaxed by human-mediated dispersal. Here, we document a case where such dispersal of a widespread species of freshwater turtle (Emydura macquarii) into the highly restricted range of a critically endangered endemic turtle (Myuchelys georgesi) has provided opportunity for the two to hybridize. This has raised concerns about the potential impact of hybridization on the endemic species, and its continued persistence in the face of challenges brought about by habitat alteration, increased competition, disease and genetic pollution. This study serves to highlight the risks associated with human-mediated dispersal, which can bring into contact species that would otherwise never or only rarely have met, and thus provide opportunities for hybridization and introgression between even distantly related species, with uncertain consequences for already threatened species.
\end{abstract}

KEY WORDS: Human-induced dispersal - Genetic pollution - Genetic swamping - Single nucleotide polymorphism

\section{INTRODUCTION}

Rare species typified by low abundances are often considered the most vulnerable to changing circumstances that drive them to the brink of extinction (Davies et al. 2000, Lawler et al. 2003). Another class of rarity (sensu Rabinowitz 1981) applies to species that are locally abundant but very restricted in distribution. For these species, local extinction means global extinction. They are particularly vulnerable to geographically restricted processes, such as local alteration of land use, local establishment of invasive predators or competitors, pollution events, pathogen outbreaks or the vicissitudes of natural events. Lo-

\footnotetext{
*Corresponding author: georges@aerg.canberra.edu.au
}

cally abundant but geographically restricted species can be recognized under criteria used to classify species as Vulnerable or Endangered (IUCN 2015). Such species rarely attract attention until they are already impacted by one or more threats, by which time options for effective mitigation may have become limited.

One neglected factor potentially impacting localized endemics is hybridization and introgression. Hybridization is remarkably common in nature. One estimate has at least $25 \%$ of plant species and $10 \%$ of animal species, mostly recently diverged species, involved in hybridization and potential introgression with other species (Mallet 2005). Reptiles were not

() The authors 2018. Open Access under Creative Commons by Attribution Licence. Use, distribution and reproduction are unrestricted. Authors and original publication must be credited. 
included in this estimate, but they too include many instances of natural hybridization. Natural hybridization among well-established species has been reported for snakes (LeClere et al. 2012), lizards (Jančúchová-Lásková et al. 2015), crocodiles (MiliánGarcía et al. 2015) and turtles (Seminoff et al. 2003). In a study of hawksbill sea turtles Eretmochelys imbricata nesting in the Bahia State in Brazil, 42\% of genotyped adults morphologically identified as hawksbill sea turtles carried mtDNA lineages of the loggerhead turtle Caretta caretta (Lara-Ruiz et al. 2006, Vilaça et al. 2012), indicating past, and potentially contemporary, hybridization. Hybrids have also been reported between $C$. caretta and the olive ridley turtle Lepidochelys olivacea, between E. imbricata and L. olivacea, and between the green sea turtle Chelonia mydas and C. caretta (Karl et al. 1995). Hybridization was considered to provide the best explanation for a species tree that strongly conflicted with the mtDNA phylogeny and traditional taxonomy for taxa within the genus Trachemys (Parham et al. 2013). Among Australian freshwater turtles, Chelodina burrungandjii and Chelodina oblonga (formerly rugosa) hybridize at their contact zone in northern Australia, C. oblonga and Chelodina canni hybridize in the rivers that drain into the Australian Gulf of Carpentaria, and C. canni and Chelodina longicollis hybridize in the lowland swamps of the Styx River of eastern Australia (Georges et al. 2002). While there is a negative correlation between instances of hybridization and level of genetic divergence between species (Mallet 2005), the above examples of intergeneric hybridization in marine turtles and between divergent lineages of Chelodina (subgenera Chelodina and Macrochelodina) suggest that partial or complete reproductive compatibility can be maintained over millions of years of independent evolution. Thus, the frequency of hybridization between species has been greatly constrained, not by evolutionary divergence in isolation, but by lack of opportunity.

This constraint is being relaxed by human-mediated dispersal, which, in freshwater turtles, is driven by a trade in turtles for pets, meat and medicinal products. Introduced species are now considered to be the second most important cause of global biodiversity loss after direct habitat destruction (McNeeley et al. 2001, Baskin 2002). A direct consequence of species intro- duction can be hybridization when the introduced species comes into contact with native species (Arnold 2004). There are now numerous instances of hybridization in the wild, even between very divergent taxa (Buskirk et al. 2005), occurring because of the inadvertent release of exotic species well outside their natural range (Fong \& Chen 2010). This is generally considered to be a deleterious process, potentially disrupting local adaptation and threatening the genetic identity of the species occupying its native range, a process referred to as genetic pollution (Fong \& Chen 2010, Rhodin et al. 2017, p. 20).

Here, we show that hybridization and introgression threaten an abundant but highly geographically restricted freshwater turtle, Myuchelys georgesi, which is endemic to the Bellinger River drainage basin, a small coastal oligotrophic river system (including the Kalang River) in northern New South Wales, Australia (Fig. 1). This drainage once flowed through a mosaic of rainforest and wet sclerophyll forest, and had a rocky substrate with open beds of coarse gravel ideally suited to stream-dwelling $M$. georgesi, but not to other short-necked species of riverine freshwater turtle. Extensive land clearing for dairy and agriculture has opened up the riparian and adjacent forest canopy and increased rates of erosion and sedimentation (Laronne et al. 1994, Telfer \& Cohen 2010), and led to the establishment of exposed sand banks suited to the nesting of a wider range of turtle species. One species taking advantage of these changes is Emydura macquarii, a polytypic species widespread in eastern and southeastern Australia (Georges \& Thomson 2010). The Bellinger River form of this species was, for a time, regarded as a distinct taxon endemic to the Bellinger River (Cogger et al.

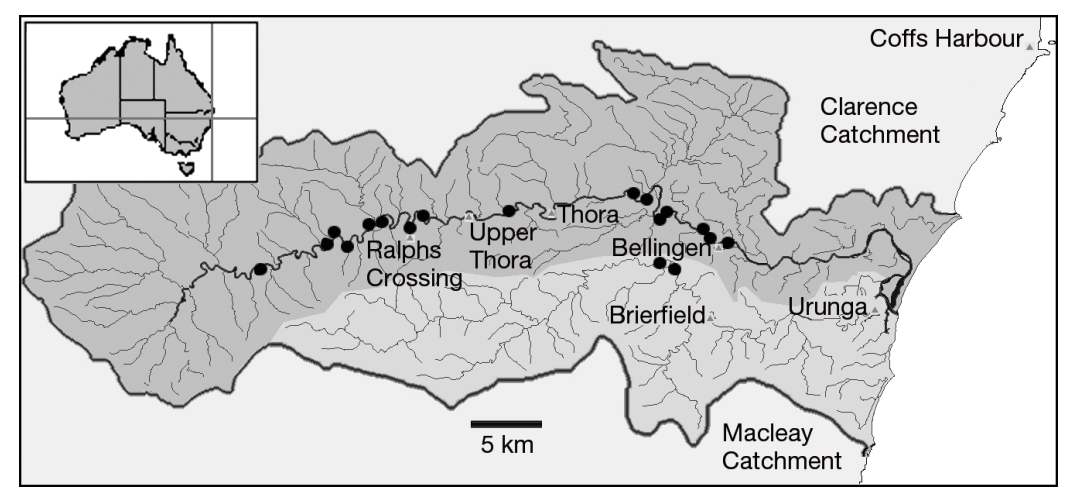

Fig. 1. Bellinger catchment (at the junction of the crosshairs in the inset) showing the capture localities of the Bellinger Emydura. The Kalang River is essentially a tributary of the Bellinger River, and is shown on the map as running through Urunga and Brierfield (lighter shading). The Bellinger and Kalang Rivers comprise the entire natural range of the now Critically Endangered Myuchelys georgesi 
1993, Cann 1998), which led to it being listed on the state and federal schedules of endangered species. Closer examination using mtDNA markers (Georges et al. 2011) revealed this second 'endemic' to be an unremarkable population of E. macquarii and, further, that it was a recent invader of the Bellinger River, probably introduced in the 1980s (see Cann 1998 for a history of its discovery) and on several occasions since. The conservation requirements of the true endemic, $M$. georgesi, were overlooked.

The introduced E. macquarii has steadily increased in abundance since the early 1990s, when it was first reported, and now poses a serious threat to the endemic $M$. georgesi through potential competition for scarce shared resources in an oligotrophic system (Chessman 1986, Allanson \& Georges 1999, Spencer et al. 2014). Furthermore, in 2015, M. georgesi suffered from a catastrophic dieback involving a virus not previously recorded from the catchment, or indeed from turtles (Jakob-Hoff et al. 2017, Zhang et al. 2018). Adult M. georgesi were effectively extirpated from their entire range, while the exotic $E$. macquarii were unaffected. The Australian government moved $M$. georgesi from unlisted to critically endangered, and the NSW Office of Environment and Heritage undertook surveys to determine the magnitude and extent of the decline, and to urgently establish an assurance breeding colony. The species is now listed as one of the 25 most endangered freshwater turtles globally (Stanford et al. 2018).

During surveys, a few animals from the Bellinger drainage showed an admixture of characters between the 2 species (Cann 1998: p. 115, top plate), and have been regarded as potential hybrids (Georges et al. 2011), though hybrids and introgressed individuals could not be reliably identified by superficial morphological examination. We addressed the question of potential hybridization and the associated challenges for management by generating a panel of single nucleotide polymorphisms (SNPs) to genotype animals for which we had existing tissue samples, including individuals suspected of being hybrids. We also genotyped the animals held in the assurance breeding colony established by the NSW Office of Environment and Heritage in collaboration with Taronga Zoo and the Western Sydney University. Our study provides an example of where next-generation DNA technologies have progressed to a point where they can be used to respond to management needs on a time frame commensurate with the need to make urgent decisions on the conservation of endangered species. Our demonstration of hybridization between E. macquarii and $M$. georgesi in the wild introduces unwelcome uncertainty into the future of the phylogenetically distinctive and critically endangered Myuchelys georgesi.

\section{MATERIALS AND METHODS}

\section{Specimen collection}

A total of 536 individuals were available for examination. These included 68 Emydura macquarii from the Bellinger River, 14 from the Kalang River, which links to the Bellinger River via a common estuary, 6 and 10 from the Hastings and MacLeay Rivers to the south, respectively, and 25 from the vicinity of the township of Coffs Harbour (Clarence drainage) to the north, a suspected source of the Bellinger River $E$. macquarii (Georges et al. 2011). The 396 Myuchelys georgesi individuals consisted of 4 individuals collected in 1985 (Georges \& Adams 1996) and 392 animals collected during surveys for and by the NSW Office of Environment and Heritage (Georges et al. 2011). Four of these were from the Kalang River. Tissue samples were typically collected from these individuals by removing a portion of the trailing webbing of the clawless toe on the rear foot, though in some cases blood was taken from the readily accessible jugular vein. Neither technique is thought to have long-term impact on the turtles (Bjorndal et al. 2010). The samples were preserved and stored in $75 \%$ ethanol, and held in storage at $-20^{\circ} \mathrm{C}$ at the University of Canberra in the UC Wildlife Tissue Collection before being subsampled for this study. An additional 18 heparinized blood samples were taken from M. georgesi originally held as an assurance colony at the University of Western Sydney, now held at Taronga Zoo (specimens TZ01 to TZ18). They were shipped to Canberra by courier and subsampled for analysis (samples AA70200 to AA70217, respectively).

\section{DNA extraction and sequencing}

Sequencing for SNP genotyping was done using DArTseq $^{\mathrm{TM}}$ (Diversity Arrays Technology Pty Ltd, www.diversityarrays.com), which uses a combination of complexity reduction using restriction enzymes, fragment size selection and next-generation sequencing, as described in detail by Kilian et al. (2012). The technique is similar to double-digest restriction associated DNA sequencing (ddRAD) (Peterson et al. 2012) but has the advantages of accepting lower 
quantities of DNA, having greater tolerance of lower quality DNA and having higher call rates (Sansaloni et al. 2011). Five commonly used combinations of restriction enzyme (HpaII, NSpI, MseI, PstI and SphI; data not presented) were evaluated for the chelid turtle E. macquarii in an earlier study (Georges et al. in press), and on that basis the restriction enzyme combination of PstI (recognition sequence 5'-CTG CAIG$\left.3^{\prime}\right)$ and SphI (5'-GCA TGIC-3') was selected for the double digestion in both $E$. macquarii and $M$. georgesi. The PstI-compatible adapter included the Illumina flow cell attachment sequence, a sequencing primer sequence, a barcode region of variable length (see Elshire et al. 2011) and the PstI-compatible overhang sequence. The reverse adapter contained a flow cell attachment sequence and an SphI-compatible overhang sequence. Only fragments generated by the PstI-SphI double digest were effectively amplified in 30 rounds of PCR. After PCR, equimolar amounts of amplification products from each sample of the 96-well microtiter plate were bulked and applied to c-Bot (Illumina) bridge PCR for sequencing on the Illumina Hiseq2500. The sequencing (single read) was run for 77 cycles.

\section{SNP genotyping}

Sequences generated from each lane were processed using proprietary DArT analytical pipelines. Approximately $2000000( \pm 7 \%)$ sequences per sample were identified and used in marker calling. Identical sequences were collapsed into files referred to as FASTQcoll files and error-corrected using a DArT Pty Ltd proprietary algorithm, which corrects a lowquality base from a singleton tag by consensus. The error-corrected FASTQcoll files were analyzed using DArT Pty Ltd proprietary software (DArTsoft14) to output candidate SNP and silicoDArT markers, which are polymorphic within the set of samples. All unique sequences from the set of FASTQcoll files were identified, and clustered by sequence similarity at a distance threshold of $3 \mathrm{bp}$ (number of different bases occupying a specific position). The sequence clusters were then parsed into SNP markers using a range of metadata parameters derived from the quantity and distribution of each sequence across all samples in the analysis: the average count for each sequence or row sum (sequencing depth), the balance of average counts for each SNP allele, and the call rate (proportion of samples for which the marker is scored). Calling quality was assured by high average read depth per locus (ca. 20x). In addition, approximately one- third of samples were processed twice from DNA to allelic calls as technical replicates, and scoring consistency (repeatability) was used as the main selection criteria for high quality/low error rate markers.

\section{Additional SNP filtering}

After receiving the SNP data from DArT Pty Ltd, the SNP data were read into a genlight object as implemented in the $\mathrm{R}$ package adegenet (Jombart 2008) to facilitate subsequent processing (Gruber et al. 2018). Stringent initial screening was undertaken on the basis of repeatability. Only loci for which the repeatability was $100 \%$ were chosen for subsequent analysis. Further filtering was undertaken on the basis of call rate. An SNP allele at a locus may not be identified during genotyping because of a concurrent mutation at one or both of the restriction enzyme recognition sites. Because of the high read depth, most 'missing data' are of this form. Only loci with a call rate of $98 \%$ or higher were included in the analyses. Finally, we filtered out duplicate SNPs from single sequenced fragments, retaining only 1 SNP selected at random. The data remaining after this additional filtering are regarded as highly reliable.

\section{Hybridization and introgression}

For qualitative assessments, we applied principal coordinates analysis (PCoA) (Gower 1966) using the centred Euclidean distance metric (functionally equivalent to Rogers' $D$ ) applied to individuals. The PCoA was implemented in the R package dartR (Gruber et al. 2018) available in the CRAN repository. The results are presented in 1 dimension because there were only 2 major clusters, corresponding to the 2 species, a decision supported by examination of the associated scree plot.

For quantitative assessments, the data were analysed with the software package NewHybrids (Anderson \& Thompson 2002) to identify individuals representing F1 and F2 hybrids and backcrosses with one or the other parental species. Strictly, this software identifies F1 hybrids, and then groups gene frequencies into classes representing different levels of hybridization (F2 and backcrosses) based on posterior probabilities, often with some overlap. In the case of the Bellinger turtles, where the introduction of Emydura macquarii is relatively recent, the interpretation of the F1, F2 and associated backcrosses is likely to be unambiguous. The power of the analysis 
was improved by inclusion of known parental genotypes, in the case of $M$. georgesi by using the samples collected in 1985, and for E. macquarii by using samples drawn from drainages adjacent to the Bellinger: Hastings-Macleay to the south, and in the vicinity of the township of Coffs Harbour (Clarence drainage) to the north. The NewHybrids software can handle only 200 loci before experiencing memory issues, a number far less than the number of loci available even after stringent filtering (7247). We selected a subset of 200 loci that were most informative in assessing hybridization, namely loci that showed fixed differences between the parental populations.

\section{RESULTS}

A total of 61244 polymorphic SNP loci were scored for the 534 individuals of Emydura macquarii and Myuchelys georgesi. After stringent filtering on repeatability (absolute repeatability) and call rate (0.98), the number of SNP loci in the data set dropped to 37906 and then 7335, respectively. Two individuals had call rates of less than $80 \%$ and were removed from the analysis (leaving $\mathrm{n}=532$ ), with the creation of 1 monomorphic locus that was also removed. Some seqeunce tags have more than 1 SNP, whereby they are included in the data by DArT Pty Ltd as separate entries. All but one of these entries were removed at random to leave 7247 loci which were used in subsequent analyses.

Genetic similarity of individuals in the PCoA established 2 clear groups corresponding to $M$. georgesi and E. macquarii (Fig. 2) on axis 1 (97.1\% of variation). Axis 2 did not represent significant variation $(0.1 \%)$. Individuals falling at positions intermediate between these 2 major groups are putative hybrids or backcrosses between F1 individuals and one or the other parental species, or individuals showing some other level of introgression.

The qualitative analysis confirmed the assignment of 63 E. macquarii from the Bellinger River and $14 E$. macquarii from the Kalang River to the species Emydura macquarii, in addition to the 41 parental E. macquarii from the Macleay, Hastings, Bellinger and Clarence (Coffs Harbour) drainages (Table 1). Similarly, the analysis confirmed the assignment of $380 \mathrm{M}$. georgesi to Myuchelys georgesi, in addition to the 4 nominated parentals collected in 1985. However, in addition, there were individuals with genetic profiles consistent with hybridization and introgression. Seven individuals ( 2 males and 5 females) had profiles most consistent with F1 hybrids (alleles universally heterozygous when fixed as alternate states in the parentals). Three of these specimens from the Kalang River were initially classified as $M$. georgesi based on superficial morphology, another specimen from the Bellinger River was originally classified as M. georgesi, and 2 specimens from the Bellinger River were originally classified as E. macquarii (Table 1). One female F1 individual (AA070217) from the Kalang River was among those transferred to the assurance colony, having been identified as $M$. georgesi. Three individuals had genetic profiles consistent with a backcross between an F1 individual and E. macquarii, and 3 individuals had genetic profiles consistent with a backcross between an F1 individual and M. georgesi. No F2 individuals were detected. All individuals from the Kalang River had genetic profiles consistent with $E$. macquarii, an F1 or a backcross between F1 and $E$. macquarii. There were no individuals in the Kalang River that assigned to pure M. georgesi.

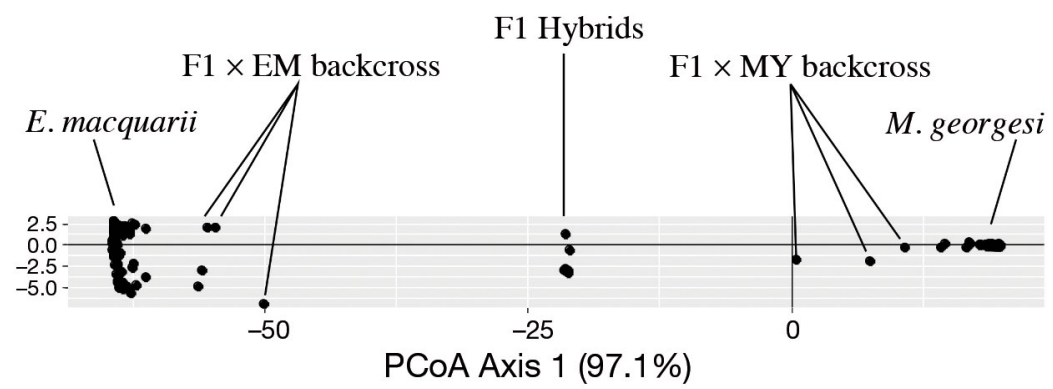

Fig. 2. A plot of genetic similarity among individuals using ordination applied to Euclidean genetic distance. Only axis 1 in the ordination contained substantial structural information $(97.1 \%)$; variation against the vertical axis is insubstantial $(0.1 \%)$, shown only to draw points out. Assignments of individuals to classes (parental Emydura macquarii [EM] and Myuchelys georgesi [MY]); F1 hybrids (F1); backcrosses of F1 hybrids to one or the other parentals, F1 $\times$ EM or F1 $\times$ MY) were made using NewHybrids (Anderson \& Thompson 2002) as implemented in the dartR package (Gruber et al. 2018). No F2 hybrids were observed

\section{DISCUSSION}

Myuchelys georgesi is one of several highly divergent species in Australia that are restricted to single drainages, presumably a result of progressive aridification of the Australian continent over the past 15 million years (Byrne et al. 2008). These species also include the Fitzroy river turtle Rheodytes leukops, restricted to the Fitzroy-Dawson drainage of eastern Queensland; the Mary River turtle Elusor macrurus, restricted to the Mary River also of eastern Queens- 
Table 1. Summary of individuals assigned to likelihood classes (parental Emydura macquarii [EM] and Myuchelys georgesi [MY]); F1 hybrids (F1); backcrosses of F1 hybrids to one or the other parentals, F1×EM or F1×MY) by NewHybrids (Anderson \& Thompson 2002). Posterior probabilities of class membership are given in the body of the table. Sample sizes (N) are summed for individuals with the same profile. The F1 hybrid in the Taronga captive colony was from the Kalang River. Gray shading indicates non-zero posterior probabilities of assignment

\begin{tabular}{|lccccccc|}
\hline Population & EM & MY & F1 & F2 & F1 $\times$ EM & F1 $\times$ MY \\
\hline Parental Emydura & 1.0000 & 0.0000 & 0.0000 & 0.0000 & 0.0000 & 0.0000 \\
Emydura (Bellinger) & 1.0000 & 0.0000 & 0.0000 & 0.0000 & 0.0000 & 0.0000 \\
Emydura (Kalang) & 1.0000 & 0.0000 & 0.0000 & 0.0000 & 0.0000 & 0.0000 \\
Emydura (Bellinger) & 0.4931 & 0.0000 & 0.0000 & 0.0000 & 0.5069 & 0.0000 \\
Emydura (Bellinger) & 0.0000 & 0.0000 & 1.0000 & 0.0000 & 0.0000 & 0.0000 \\
Myuchelys (Bellinger) & 0.0000 & 0.0000 & 1.0000 & 0.0000 & 0.0000 & 0.0000 \\
Myuchelys (Kalang) & 0.0000 & 0.0000 & 1.0000 & 0.0000 & 0.0000 & 0.0000 \\
Myuchelys (Taronga) & 0.0000 & 0.0000 & 1.0000 & 0.0000 & 0.0000 & 0.0000 \\
Emydura (Bellinger) & 0.0000 & 0.0000 & 0.0000 & 0.0000 & 1.0000 & 0.0000 \\
Myuchelys (Kalang) & 0.0000 & 0.0000 & 0.0000 & 0.0000 & 1.0000 & 0.0000 \\
Myuchelys (Bellinger) & 0.0000 & 0.0000 & 0.0000 & 0.0000 & 0.0000 & 1.0000 \\
Myuchelys (Bellinger) & 0.0000 & 0.9994 & 0.0000 & 0.0000 & 0.0000 & 0.0006 \\
Myuchelys (Bellinger) & 0.0000 & 1.0000 & 0.0000 & 0.0000 & 0.0000 & 0.0000 \\
Myuchelys (Taronga) & 0.0000 & 1.0000 & 0.0000 & 0.0000 & 0.0000 & 0.0000 \\
Parental Myuchelys & 0 & 1.0000 & 0.0000 & 0.0000 & 0.0000 & 0.0000 & 1 \\
& & & & & 1 \\
\end{tabular}

land; the Manning River turtle Myuchelys purvisi, found only in the Barnard-Manning River of eastern New South Wales; the western sawshell turtle Myuchelys belli, from the granitic headwater streams of the Murray-Darling drainage; and the western swamp turtle Pseudemydura umbrina of southeast Western Australia. These species are vulnerable simply because of their highly restricted distributions, regardless of local abundance (Georges 1993), and many deserve greater attention than they currently receive in conservation planning. $P$. umbrina has long been classified as Critically Endangered, but the case of $M$. georgesi serves to highlight how quickly a species with a restricted distribution (in this case, ca. $60 \mathrm{~km}$ of riverine habitat) can move from being secure to critically endangered. Two primary influences appear to be the cause: a rapidly spreading virus causing blindness and poor vigor that virtually extirpated the adult population in a matter of months (Jakob-Hoff et al. 2017, Zhang et al. 2018); and the founding of a population of the widespread generalist species Emydura macquarii (sensu Georges \& Thomson 2010) in the Bellinger catchment. Its subsequent rapid increase in distribution and abundance within the oligotrophic Bellinger River has raised concerns that it is displacing the more specialized $M$. georgesi through competition for food, as the 2 species have considerable overlap in diet (Chessman 1986, Allanson \& Georges 1999, Spencer et al. 2014). To this, we now add a risk that E. macquarii and $M$. georgesi are hybridizing, despite their having diverged in the Lower Cretaceous (Ferreira et al. 2018), with 5 F1 hybrids detected, and evidence of backcrossing to the parental types. The F1 individuals are presumably fertile, as indicated by the presence of backcrosses, and the absence of F2 individuals is assumed to be the result of their low frequency in the population and sampling intensity. E. macquarii has genotypic sex determination, as do all chelid turtles studied so far (Bull et al. 1985, Georges 1988, Thompson 1988, Georges \& McInnes 1998), and chromosome number $2 \mathrm{n}=50$ (Martinez et al. 2008). The karyotype of $M$. georgesi has not yet been described and so chromosomal homology across the 2 species has not been studied in detail.

Erosion of genetic variability in geographically restricted endemics increases vulnerability (Lande \& Barrowclough 1987, Újvári et al. 2002). Low genetic diversity may indeed have contributed to the efficacy of the virus in killing $M$. georgesi while leaving the introduced E. maquarii and naturally resident Chelodina longicollis unaffected. In this context, some level of hybridization and horizontal transfer of alleles is not necessarily cause for concern. Injection of novel alleles may rescue genetic variability in the endemic species, increase its adaptive potential, and increase its resilience to future change in response to disease and environmental change (Becker et al. 2013, Hedrick 2013, Stelkens et al. 2014, Pfennig et al. 2016, Meier et al. 2017, Phillips et al. 2018). An example of genetic rescue is provided by the Florida panther Puma concolor coryi, in which 8 individuals from 
another subspecies in Texas ( $P$. c. stanleyana) were introduced to Florida (Johnson et al. 2010). Panther numbers in Florida have since increased threefold, genetic heterozygosity has doubled, survival and fitness indices have improved, and inbreeding correlates have declined significantly (Johnson et al. 2010). Similar success was achieved in restoration of an inbred population of the adder Vipera berus (Madsen et al. 1999). Recruitment of new alleles via hybridization occurs regularly without assistance from humans, and genetic variation arising from natural hybridization has conservation value. Thus, natural introgression between sympatric or parapatric sister species could be considered an in situ conservation strategy, particularly where the pure species are at risk of extinction (Becker et al. 2013). However, as E. macquarii has come to dominate the freshwater turtle fauna of the Bellinger River, the risk is that the genetics of the endemic species will be compromised by swamping (sensu Todesco et al. 2016) through increasing levels of hybridization and introgression. Indeed, in the Kalang River, all specimens of $M$. georgesi were either F1 hybrids or showed some level of introgression. We believe that the situation in the Kalang River provides a window to the future of the population of $M$. georgesi in the Bellinger River and supports the contention that the process is one of genetic swamping.

This presents a serious conundrum for managers and the community more broadly. Do we intervene to manage the steadily increasing population of E. macquarii, or do we let nature run its course? E. macquarii is not endemic to the Bellinger River drainage but is widespread in adjacent river systems (the Macleay River to the south; Clarence River to the north) and throughout eastern Australia. Translocation of specimens of E. macquarii from the Bellinger River back to their native range is not an option because of the risk of disease spread, the known virus being of particular concern. Euthanasia may need to be considered as a management option. Such an option has been adopted in the management of native populations of the endangered European white-headed duck Oxyura leucocephala in Spain and the United Kingdom, where it is threatened by hybridization with the more genetically diverse ruddy duck Oxyura jamaicensis introduced from North America (Muñoz-Fuentes et al. 2007). Management of Australian native vertebrates through lethal techniques has proven controversial and led to community backlash in many instances (Warburton \& Norton 2009). E. macquarii may now also fill a role in the ecosystem that $M$. georgesi was filling before the disease outbreak. Hence, the question of inter- vention is not solely based on risks of hybridization or competition between E. macquarii and M. georgesi. Management must balance the impacts that a steadily increasing population of E. macquarii will have on $M$. georgesi with broader ecological, community considerations and disease risk.

The prospect of hybrids in the natural population of $M$. georgesi is also clearly a concern when establishing a captive assurance colony. Until now, it was not possible to address this issue adequately using available mitochondrial sequences alone. We were able to identify an F1 hybrid among the animals taken from the wild to establish the assurance colony before the animals were brought together for breeding. That animal was removed so that we now can be certain that any head-started individuals returned to the river are genetically pure $M$. georgesi and not inadvertently contaminated with alleles from E. macquarii.

In summary, we contend that genetic swamping by the increasing population of E. macquarii is an additional major risk to the already critically endangered M. georgesi. This should inform management decisions on the likely efficacy of release of captive-bred $M$. georgesi into the wild and on the priority given to management of the impact of the introduced $E$. macquarii. As these 2 species are distantly related (Georges \& Adams 1992, Georges et al. 1999, Fielder 2013, Ferreira et al. 2018), this study also serves to reinforce perceptions of the risks associated with human-mediated dispersal more generally. Such human-mediated dispersal can bring into contact species that would otherwise never or only rarely have met, and so provide opportunity for hybridization and introgression between even distantly related species, with uncertain consequences for already threatened species.

Data availability. Data used in this paper have been deposited with Dryad (doi: https://doi.org/10.5061/dryad.6p5kd34) together with the R scripts used to generate the results.

Conflict of interest. A.K., as the director of Diversity Arrays Technology Pty Ltd, declares a potential conflict of interest in that the data were generated by his company. All other authors have declared that they have no conflict of interest.

Acknowledgements. We would like to thank the many people, too many to mention by name, who assisted with the collection of samples for this study, and in particular H. B. Shaffer, Carla Eisemberg, Darren Fielder, David Judge, Kristen Petrov, Josh Maher, Karrie Rose, Bruce Chessman. This paper was prepared during the Science Writers' Retreat held in Kioloa, NSW, in July 2018, and benefited greatly from the comments of Gerry McGilvrey and Shane Ruming of the Ecosystems and Threatened Species Unit, Office of Environment and Heritage, Coffs Harbour, NSW, Australia. 


\section{LITERATURE CITED}

Allanson M, Georges A (1999) Diet of Elseya purvisi and Elseya georgesi, a sibling species pair of freshwater turtles from Eastern Australia. Copeia 1999:473-477

Anderson EC, Thompson EA (2002) A model-based method for identifying species hybrids using multilocus genetic data. Genetics 160:1217-1229

Arnold ML (2004) Natural hybridization and the evolution of domesticated, pest and disease organisms: natural hybridization and evolution. Mol Ecol 13:997-1007

Baskin Y (2002) A plague of rats and rubbervines: the growing threat of species invasions. Island Press, Washington, DC, USA

Becker M, Gruenheit N, Steel M, Voelckel C and others (2013) Hybridization may facilitate in situ survival of endemic species through periods of climate change. Nat Clim Chang 3:1039-1043

Bjorndal KA, Reich KJ, Bolten AB (2010) Effect of repeated tissue sampling on growth rates of juvenile loggerhead turtles Caretta caretta. Dis Aquat Org 88:271-273

* Bull JJ, Legler JM, Vogt RC (1985) Non-temperature dependent sex determination in two suborders of turtles. Copeia 1985:784-786

Buskirk J, Parham JF, Feldman CR (2005) On the hybridisation between two distantly related Asian turtles (Testudines: Sacalia $\times$ Mauremys). Salamandra (Frankf) 41: $21-26$

Byrne M, Yeates DK, Joseph L, Kearney M and others (2008) Birth of a biome: insights into the assembly and maintenance of the Australian arid zone biota. Mol Ecol 17: 4398-4417

Cann J (1998) Australian freshwater turtles. Beaumont Publishing, Singapore

Chessman BC (1986) Diet of the Murray turtle, Emydura macquarii (Gray) (Testudines, Chelidae). Wildl Res 13: 65-69

Cogger H, Cameron E, Sadlier R, Eggler P (1993) The Action Plan for Australian Reptiles. Environment Australia (formerly Australian Nature Conservation Agency), Canberra. http://155.187.2.69/biodiversity/threatened/publications/action/reptiles/pubs/action-plan-for-reptiles.pdf (accessed 15 Nov 18)

Davies KF, Margules CR, Lawrence JF (2000) Which traits of species predict population declines in experimental forest fragments? Ecology 81:1450-1461

Elshire RJ, Glaubitz JC, Sun Q, Poland JA, Kawamoto K, Buckler ES, Mitchell SE (2011) A robust, simple genotyping-by-sequencing (GBS) approach for high diversity species. PLOS ONE 6:e19379

Ferreira GS, Bronzati M, Langer MC, Sterli J (2018) Phylogeny, biogeography and diversification patterns of side-necked turtles (Testudines: Pleurodira). R Soc Open Sci 5:171773

Fielder D (2013) Ancient phenotypes revealed through present day species - a morphological analysis of Australia's saw-shelled turtles including the threatened Myuchelys bellii (Testudines: Chelidae). Chelonian Conserv Biol 12: 101-111

Fong JJ, Chen TH (2010) DNA evidence for the hybridization of wild turtles in Taiwan: possible genetic pollution from trade animals. Conserv Genet 11:2061-2066

Georges A (1988) Sex determination is independent of incubation temperature in another chelid turtle, Chelodina longicollis. Copeia 1988:248-254
Georges A (1993) Setting conservation priorities for Australian freshwater turtles. In: Lunney D, Ayers D (eds) Herpetology in Australia - a diverse discipline. Royal Society of New South Wales, Sydney, p 49-58

Georges A, Adams M (1992) A phylogeny for Australian chelid turtles based on allozyme electrophoresis. Aust J Zool 40:453-476

Georges A, Adams M (1996) Electrophoretic delineation of species boundaries within the short-necked chelid turtles of Australia. Zool J Linn Soc 118:241-260

Georges A, McInnes S (1998) Temperature fails to influence hatchling sex in another genus and species of chelid turtle, Elusor macrurus. J Herpetol 32:596-598

Georges A, Thomson S (2010) Diversity of Australasian freshwater turtles, with an annotated synonymy and keys to species. Zootaxa 2496:1-37

* Georges A, Birrell J, Saint K, McCord WP, Donnellan S (1999) A phylogeny for side-necked turtles (Chelonia: Pleurodira) based on mitochondrial and nuclear gene sequences. Biol J Linn Soc 67:213-246

Georges A, Adams M, McCord W (2002) Electrophoretic delineation of species boundaries within the genus Chelodina (Testudines: Chelidae) of Australia, New Guinea and Indonesia. Zool J Linn Soc 134:401-421

Georges A, Spencer RJ, Welsh M, Shaffer HB, Walsh R, Zhang X (2011) Application of the precautionary principle to taxa of uncertain status: the case of the Bellinger River turtle. Endang Species Res 14:127-134

Georges A, Gruber B, Pauly GB, White D and others (in press) Genome-wide SNP markers breathe new life into phylogeography and species delimitation for the problematic short-necked turtles (Chelidae: Emydura) of eastern Australia. Mol Ecol, doi:10.1111/mec.14925

Gower JC (1966) Some distance properties of latent root and vector methods used in multivariate analysis. Biometrika 53:325-338

* Gruber B, Unmack PJ, Berry OF, Georges A (2018) dartR: An $R$ package to facilitate analysis of SNP data generated from reduced representation genome sequencing. Mol Ecol Resour 18:691-699

*Hedrick PW (2013) Adaptive introgression in animals: examples and comparison to new mutation and standing variation as sources of adaptive variation. Mol Ecol 22: 4606-4618

* IUCN (2015) The IUCN Red List of Threatened Species. Version 2018-2. https://www.iucnredlist.org/search?query= Elseya \%20georgesi\&searchType=species (accessed 15 Nov 18)

Jakob-Hoff R, Lees CM, McGilvray G, Ruming S and others (eds) (2017) Status review, disease risk analysis and conservation action plan for the Bellinger River snapping turtle. IUCN SSC Conservation Breeding Specialist Group, Apple Valley, MN

Jančúchová-Lásková J, Landová E, Frynta D (2015) Are genetically distinct lizard species able to hybridize? A review. Curr Zool 61:155-180

Johnson WE, Onorato DP, Roelke ME, Land ED and others (2010) Genetic restoration of the Florida panther. Science 329:1641-1645

* Jombart T (2008) adegenet: a R package for the multivariate analysis of genetic markers. Bioinformatics 24:14031405

Karl SA, Bowen BW, Avise JC (1995) Hybridization among the ancient mariners: characterization of marine turtle hybrids with molecular genetic assays. J Hered 86:262-268 
Kilian A, Wenzl P, Huttner E, Carling J and others (2012) Diversity arrays technology: a generic genome profiling technology on open platforms. Meth Mol Biol 888:67-89

Lande R, Barrowclough GR (1987) Effective population size, genetic variation, and their use in population management. In: Soulé ME (ed) Viable populations for conservation. Cambridge University Press, Cambridge, MA, p 87-123

*ara-Ruiz P, Lopez GG, Santos FR, Soares LS (2006) Extensive hybridization in hawksbill turtles (Eretmochelys imbricata) nesting in Brazil revealed by mtDNA analyses. Conserv Genet 7:773-781

Laronne JB, Outhet DN, Carling PA, McCabe TJ (1994) Scour chain employment in gravel bed rivers. Catena 22: 299-306

Lawler JJ, White D, Sifneos JC, Master LL (2003) Rare species and the use of indicator groups for conservation planning. Conserv Biol 17:875-882

LeClere JB, Hoaglund EP, Scharosch J, Smith CE, Gamble T (2012) Two naturally occurring intergeneric hybrid snakes (Pituophis catenifer sayi $\times$ Pantherophis vulpinus; Lampropeltini, Squamata) from the midwestern United States. J Herpetol 46:257-262

Madsen T, Shine R, Olsson M, Wittzell H (1999) Restoration of an inbred adder population. Nature 402:34-35

Mallet J (2005) Hybridization as an invasion of the genome. Trends Ecol Evol 20:229-237

Martinez PA, Ezaz T, Valenzuela N, Georges A, Marshall Graves JA (2008) An XX/XY heteromorphic sex chromosome system in the Australian chelid turtle Emydura macquarii: a new piece in the puzzle of sex chromosome evolution in turtles. Chromosome Res 16:815-825

McNeeley JA, Mooney HA, Neville LE, Shei P, Waage JK (2001) A global strategy on invasive alien species. Center for Agriculture and Bioscience (CAB) International, Wallingford

Meier JI, Marques DA, Mwaiko S, Wagner CE, Excoffier L, Seehausen O (2017) Ancient hybridization fuels rapid cichlid fish adaptive radiations. Nat Commun 8: 14363

Milián-García Y, Ramos-Targarona R, Pérez-Fleitas E, SosaRodríguez G and others (2015) Genetic evidence of hybridization between the critically endangered Cuban crocodile and the American crocodile: implications for population history and in situ/ex situ conservation. Heredity 114:272-280

* Muñoz-Fuentes V, Vilà C, Green AJ, Negro JJ, Sorenson MD (2007) Hybridization between white-headed ducks and introduced ruddy ducks in Spain. Mol Ecol 16: 629-638

Parham JF, Papenfuss TJ, van Dijk PP, Wilson BS, Marte C, Schettino LR, Simison BW (2013) Genetic introgression and hybridization in Antillean freshwater turtles (Trachemys) revealed by coalescent analyses of mitochondrial and cloned nuclear markers. Mol Phylogenet Evol 67: 176-187

`Peterson BK, Weber JN, Kay EH, Fisher HS, Hoekstra HE (2012) Double digest RADseq: an inexpensive method for de novo SNP discovery and genotyping in model and non-model species. PLOS ONE 7(5):e37135

Pfennig KS, Kelly AL, Pierce AA (2016) Hybridization as a facilitator of species range expansion. Proc R Soc B 283: 20161329

Editorial responsibility: David Richardson, Norwich, UK
Phillips KP, Cable J, Mohammed RS, Herdegen-Radwan M and others (2018) Immunogenetic novelty confers a selective advantage in host-pathogen coevolution. Proc Natl Acad Sci USA 115:1552-1557

Rabinowitz D (1981) Seven forms of rarity. In: Synge H (ed) The biological aspects of rare plant conservation. Wiley, New York, NY, p 205-217

Rhodin AGJ, Iverson JB, Bour R, Fritz U, Georges A, Shaffer HB, van Dijk PP (Turtle Taxonomy Working Group) (2017) Turtles of the world: annotated checklist and atlas of taxonomy, synonymy, distribution, and conservation status. 8th edn. Conserv Monogr 7:1-292

Sansaloni C, Petroli C, Jaccoud D, Carling J, Detering F, Grattapaglia D, Kilian A (2011) Diversity Arrays Technology (DArT) and next-generation sequencing combined: genome-wide, high throughput, highly informative genotyping for molecular breeding of Eucalyptus. BMC Proceedings 5(Suppl 7):P54

Seminoff JA, Karl SA, Schwartz T, Resendiz A (2003) Hybridization of the green turtle (Chelonia mydas) and hawksbill turtle (Eretmochelys imbricata) in the Pacific Ocean: indication of an absence of gender bias in the directionality of crosses. Bull Mar Sci 73:643-652

Spencer RJ, Georges A, Lim D, Welsh M, Reid AM (2014) The risk of inter-specific competition in Australian shortnecked turtles. Ecol Res 29:767-777

* Stanford CB, Rhodin AGJ, van Dijk PP, Horne BD and others (2018) Turtles in trouble. The world's 25+ most endangered tortoises and freshwater turtles - 2018. Turtle Conservancy, Ojai, CA. www.iucn-tftsg.org/wp-content/ uploads/file/Top\%2025/Turtle_Conservation_Coalition_ 2018_Top_25+_Turtles_in_Trouble_lr.pdf (accessed $1 \overline{5}$ Nov 18)

K Stelkens RB, Brockhurst MA, Hurst GDD, Greig D (2014) Hybridization facilitates evolutionary rescue. Evol Appl 7:1209-1217

Telfer D, Cohen T (2010) Bellinger and Kalang River estuaries erosion study. Report prepared for Bellingen Shire Council. GECO Environmental, Grassy Head, NSW

Thompson MB (1988) Influence of incubation temperature and water potential on sex determination in Emydura macquarii (Testudines: Pleurodira). Herpetologica 44: 86-90

Todesco M, Pascual MA, Owens GL, Ostevik KL and others (2016) Hybridization and extinction. Evol Appl 9: 892-908

Újvári B, Madsen T, Kotenko T, Olsson M, Shine R, Wittzell $\mathrm{H}$ (2002) Low genetic diversity threatens imminent extinction for the Hungarian meadow viper (Vipera ursinii rakosiensis). Biol Conserv 105:127-130

Vilaça ST, Vargas SM, Lara-Ruiz P, Molfetti É and others (2012) Nuclear markers reveal a complex introgression pattern among marine turtle species on the Brazilian coast: hybridization among sea turtles. Mol Ecol 21: 4300-4312

*Warburton B, Norton BG (2009) Towards a knowledgebased ethic for lethal control of nuisance wildlife. J Wildl Manag 73:158-164

Zhang J, Finlaison DS, Frost MJ, Gestier S and others (2018) Identification of a novel nidovirus as a potential cause of large scale mortalities in the endangered Bellinger River snapping turtle (Myuchelys georgesi). PLOS ONE 13(10):e0205209

Submitted: July 30, 2018; Accepted: October 1, 2018

Proofs received from author(s): November 15, 2018 